\title{
The Effect of Nitrogen Starvation on the Activity of Nitrate Reductase and other Enzymes in Chlorella
}

\author{
BY I. MORRIS AND P. J. SYRETT \\ Department of Botany, University College London, W.C. 1
}

(Received 27 May 1964)

SUMMARY

Chlorella vulgaris grown with nitrate as nitrogen source had high nitrate reductase activity. During nitrogen starvation the rate of nitrate assimilation increased but the specific activity of nitrate reductase in extracts decreased sharply; a similar decrease occurred after transfer to an ammonium medium. Organisms grown with ammonium as nitrogen source did not assimilate nitrate but acquired the ability to do so after nitrogen starvation; nitrate reductase activity in these organisms was initially very low but increased during nitrogen starvation and then decreased. After $18 \mathrm{hr}$ of nitrogen starvation ammonium-grown and nitrate-grown organisms assimilated nitrate rapidly at a rate some ten times greater than the activity of nitrate reductase in cell-free extracts would allow. The specific activity of glutamic dehydrogenase was about $40 \%$ higher in extracts from ammonium-grown organisms than in extracts from nitrategrown organisms and its activity increased by 40-100\% during nitrogen starvation. The activity of malic dehydrogenase was unaffected by $18 \mathrm{hr}$ of nitrogen starvation. The activity of isocitrate lyase decreased by about one-quarter when acetate was present but decreased much more markedly when the organisms were nitrogen-starved in the presence of glucose.

\section{INTRODUCTION}

Ammonium- $\mathrm{N}$ is assimilated much more rapidly by nitrogen-starved Chlorella vulgaris than by normal organisms (Syrett, 1953; Bongers, 1956). Generally the rate of nitrate assimilation also is higher, although the difference is less marked (Bongers, 1956; Syrett, 1956). Nothing is known of the changes in cellular enzymic composition which may occur during nitrogen starvation. Following recent investigations into the control of nitrate assimilation in Chlorella (Syrett \& Morris, 1963; Morris \& Syrett, 1963) we have measured changes in the rate of nitrate assimilation and in nitrate reductase activity during nitrogen starvation. The effect on some other enzyme activities was also studied for comparison.

\section{METHODS}

Chlorella vulgaris (Pearsall strain) was grown under sterile conditions as described in a previous paper (Syrett \& Morris, 1963). Nitrate assimilation was followed by measuring the disappearance of nitrate from the medium with a colorimetric phenol disulphonic acid method (Syrett \& Morris, 1963).

Preparation of nitrogen-starved organisms. Autotrophically grown organisms were harvested by centrifugation ( $500 \mathrm{~g}$ for $5 \mathrm{~min}$.), washed and resuspended in nitrogen- 
free growth medium. In some experiments, the cultures were then illuminated (tungsten-filament lamp giving about 600 foot-candles to cultures) and aerated with air containing $0.5 \%(\mathrm{v} / \mathrm{v})$ carbon dioxide for $18 \mathrm{hr}$. In other experiments, glucose $(2 \%, \mathrm{w} / \mathrm{v}$, final concentration) was added to the cultures, which were then aerated for $18 \mathrm{hr}$ in darkness. The temperature was always $25^{\circ}$. Comparative results showed that both methods of nitrogen starvation induced similar changes in nitrate assimilation and in nitrate reductase activity.

Preparation of cell-free extracts. Organisms suspended in $0 \cdot 1 \mathrm{M}$-tris $+\mathrm{HCl}$ buffer ( $\mathrm{pH} \mathrm{7 \cdot 4)}$ ) were passed through a French pressure cell (Morris \& Syrett, 1963), centrifuged at $10,000 \mathrm{~g}$ for $20 \mathrm{~min}$. and the supernatant fluid used for determination of enzyme activities. Protein contents of the extracts were determined by the method of Lowry, Rosebrough, Farr \& Randall (1951) with bovine albumin dissolved in tris buffer as a standard.

Nitrate reductase activity. This was determined by measuring the rate of nitrite formation from nitrate as described by Morris \& Syrett (1963).

Malic dehydrogenase activity. This was determined by measuring the oxidation of NADH in the presence of oxaloacetate and cell extract. The reaction mixture contained, in $2.5 \mathrm{ml} ., 210 \mu$ moles tris buffer ( $\mathrm{pH} 7 \cdot 4$ ); $25 \mu$ moles oxaloacetate and $0 \cdot 15 \mathrm{mg}$. NADH. Extract containing about $10 \mu \mathrm{g}$. protein was added at zero time and the change in light extinction at $340 \mathrm{~m} \mu$ measured. The incubation temperature was $22-26^{\circ}$. The change in extinction was linear with time for $5 \mathrm{~min}$. following the addition of cell extract and the rate of change was proportional to the volume of extract added.

Glutamic dehydrogenase activity. This was measured by following the oxidation of NADPH in the presence of $\alpha$-oxoglutarate, ammonium and cell extract. The reaction mixture contained in $2.5 \mathrm{ml}$.: $185 \mu$ moles tris buffer $(\mathrm{pH} 7 \cdot 4$ ); $25 \mu$ moles $\left(\mathrm{NH}_{4}\right)_{2} \mathrm{SO}_{4} ; 25 \mu$ moles $\alpha$-oxoglutarate; $0 \cdot 15 \mathrm{mg}$. NADPH. Cell extract containing about 100-200 $\mu \mathrm{g}$. protein was added at zero time and change in extinction at $340 \mathrm{~m} \mu$ measured. Incubation temperature was $22-26^{\circ}$. The rate of reaction was constant for $5 \mathrm{~min}$. after the addition of extract and proportional to the volume of extract added.

Isocitrate lyase activity. This was measured by determining the rate of glyoxylate formation from isocitrate catalysed by frozen suspensions of acetate-adapted organisms (Syrett, Merrett \& Bocks, 1963).

\section{RESULTS}

The effect of nitrogen starvation on the rate of nitrate assimilation

Chlorella vulgaris (Pearsall strain) grown with ammonium sulphate as sole source of nitrogen did not assimilate nitrate until after a delay of $2-3 \mathbf{~ h r}$, whereas organisms grown with potassium nitrate assimilated nitrate immediately (Fig. 1a). After incubation in nitrogen-free medium for $4 \mathrm{hr}$, ammonium-grown organisms assimilated nitrate immediately and at a rate equal to that of similarly treated nitrate-grown organisms (Fig. 1b). More prolonged nitrogen starvation increased the rate at which nitrate was assimilated by both types of organism (Fig. 1c).

Assimilation of nitrate by nitrogen-starved organisms was accompanied by rapid changes of oxygen uptake and carbon dioxide output (Syrett, 1956). Manometric 
study of these gas exchanges is a sensitive method for detecting nitrate assimilation. Such studies confirmed that nitrate assimilation by nitrogen-starved organisms (whether grown on potassium nitrate or ammonium sulphate) was immediate.

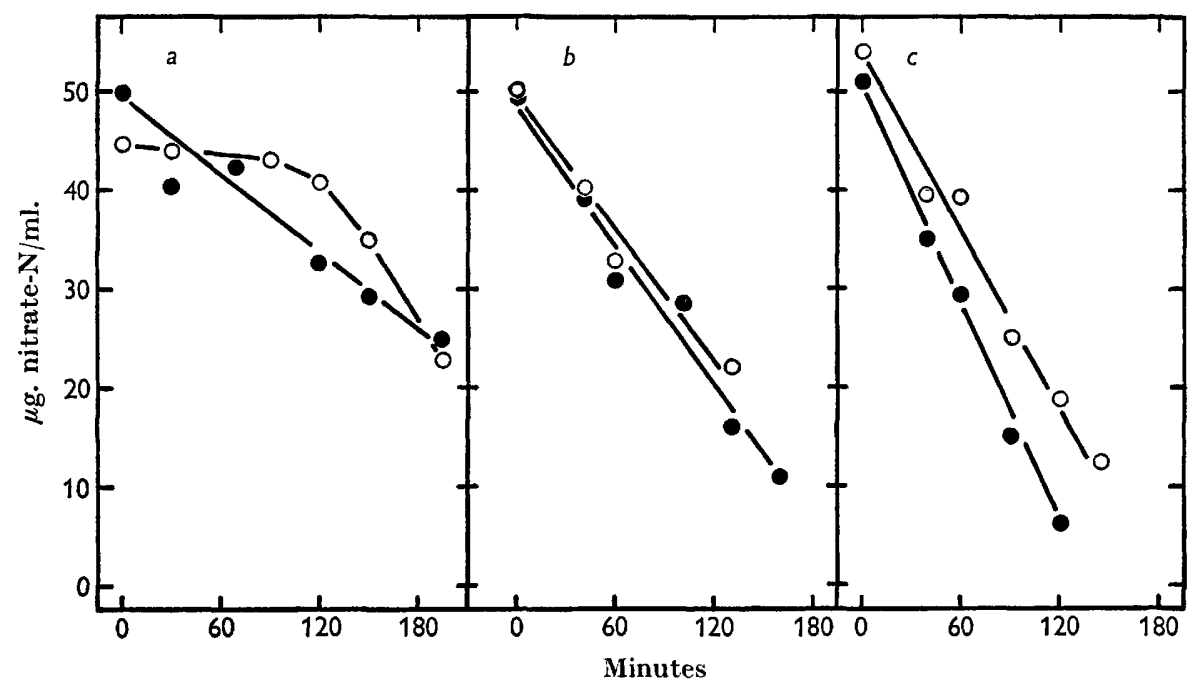

Fig. 1. The assimilation of nitrate by nitrate-grown (-0-9-) and ammonium-grown (-O-O-) Chlorella vulgaris after $(a) 0,(b) 4,(c) 16 \mathrm{hr}$ of nitrogen starvation. Nitrogen starvation was done by incubating cultures $\left(3.2 \mathrm{mg}\right.$. dry wt. $/ \mathrm{ml}$.) at $25^{\circ}$ with $2 \%(\mathrm{w} / \mathrm{v})$ glucose. Samples were removed at suitable times, the concentration adjusted to equiv. 6.4 mg. dry wt. $/ \mathrm{ml}$. in fresh $\mathrm{N}$-free medium and nitrate added. The cultures were then incubated in darkness at $25^{\circ}$ with $1 \%(w / v)$ glucose present and the disappearance of nitrate from the medium was followed.

\section{Changes in nitrate reductase activity during nitrogen starvation}

Rates of nitrate assimilation by Chlorella incubated in nitrogen-free medium for different periods of time, together with the accompanying changes in nitrate reductase, are summarized in Fig. 2 . The nitrate reductase activity of nitrate-grown organisms was initially high and this decreased markedly during nitrogen starvation. A comparable decrease in nitrate reductase activity was found when nitrate-grown organisms were transferred to an ammonium medium (Fig. 3). The nitrate reductase activity of ammonium-grown organisms was negligible initially; it increased during the first $4 \mathrm{hr}$ of nitrogen starvation and reached a value corresponding to 6-12 units of enzyme activity. After remaining constant for some time, the activity decreased and, after $18 \mathrm{hr}$ of nitrogen starvation, extracts from both ammonium- and nitrategrown organisms had the same rather low activity, namely about 1-3 units (Fig. 2). The decline in nitrate reductase shown in Figs. 2 and 3 is a decrease in specific activity; that is, it is a decrease in relation to general cellular protein. During these experiments there was little significant increase in number of organisms (e.g. top of Fig. 3); the decrease in nitrate reductase activity was not, therefore, a consequence of dilution due to multiplication.

The decline of specific activity may be due either to a loss of nitrate reductase protein or to loss of some essential cofactor(s). Addition to extracts of possible cofactors (e.g. flavin adenine dinucleotide, flavin-mononucleotide) had no effect 
on nitrate reductase activity in extracts from normal or nitrogen-starved organisms. When an extract from normal nitrate-grown organisms was mixed with that from nitrogen-starved organisms no stimulation of activity was observed; a stimulation might be expected if some unknown cofactor was present in extracts from normal organisms but absent from extracts of nitrogen-starved organisms.

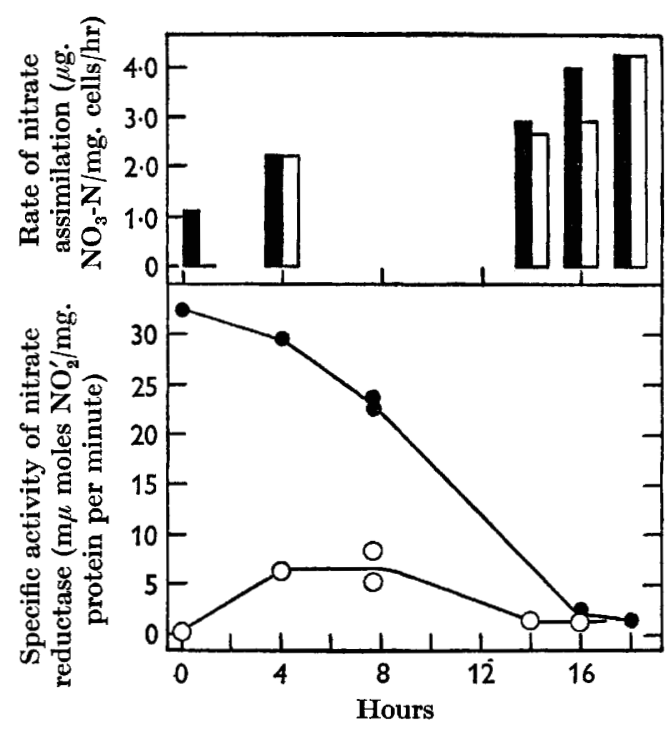

Fig. 2

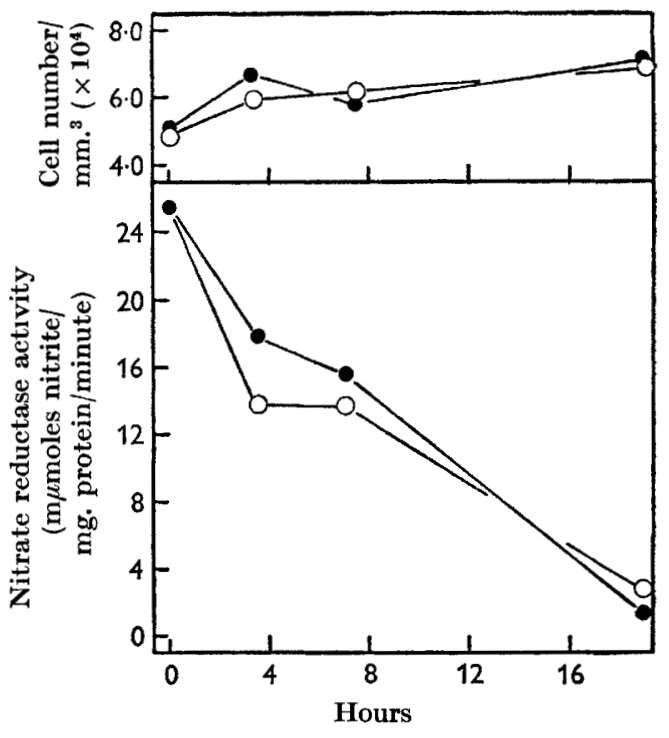

Fig. 3

Fig. 2. Changes in the rate of nitrate assimilation (upper graph) and nitrate reductase activity (lower) when ammonium-grown Chlorella vulgaris (open symbols) and nitrategrown C. vulgaris (black symbols) were incubated in nitrogen-free medium in darkness at $\mathbf{2 5}^{\circ}$ with $2 \%(\mathrm{w} / \mathrm{v})$ glucose present. Samples were removed at suitable times and after resuspending the organisms in ice-cold tris buffer cell-free extracts were made and nitrate reductase activity measured. Other samples were resuspended in fresh $\mathbf{N}$-free medium, the concentration adjusted to equiv. $6.4 \mathrm{mg}$. dry $\mathrm{wt} . / \mathrm{ml}$. and nitrate added. The cultures were then incubated in darkness at $25^{\circ}$ with $1 \%(w / v)$ glucose present and the disappearance of nitrate from the medium followed for $150 \mathrm{~min}$.

Fig. 3. Changes in nitrate reductase activity in cell-free extracts of Chlorella vulgaris when nitrate-grown organisms were transferred to nitrogen-free medium (-0-0-), or to medium containing 0.01 $\mathrm{m}$-ammonium sulphate (-O-O-). Concentration of organism equiv. $\mathbf{2 \cdot 0} \mathrm{mg}$. dry wt. $/ \mathrm{ml}$. The suspensions were incubated at $25^{\circ}$ in darkness with $2 \%(\mathrm{w} / \mathrm{v})$ glucose present. The upper part of the figure shows little change in number of organisms during the experiment.

Morton, Dickerson \& England (1960) observed an increase in proteinase activity when Penicillium griseofulvum was starved of nitrogen. High proteinase activity in nitrogen-starved Chlorella might destroy nitrate reductase during extraction; the extracts would then have less enzyme activity than extracts from normal Chlorella. To test this hypothesis, suspensions of normal and nitrogen-starved organisms were mixed before preparing extracts. An active proteinase might be expected to depress the activity extracted from the mixed suspension; no such depression was observed. Consequently the evidence at present available suggests that the decline in nitrate reductase activity which accompanied nitrogen starvation represented a real loss of nitrate reductase protein from the organisms. 


\section{Comparison of nitrate reductase activity in cell-free extracts with the rate of nitrate assimilation by intact Chlorella}

The average nitrate reductase activity extracted from nitrate-grown organisms corresponded to the formation of about $1.8 \mu$ moles nitrite $/ \mathrm{mg}$. protein $/ \mathrm{hr}$. After complete breakage, equiv. $1 \mathrm{mg}$. dry wt organisms gave $0.24 \mathrm{mg}$. protein in the supernatant fluid of the cell-free extract. Thus a cell-free extract from equiv. $1 \mathrm{mg}$. dry wt organism contained sufficient nitrate reductase activity to reduce about $6 \mu \mathrm{g}$. nitrate-N/hr. The observed rate of nitrate reduction by whole organisms was

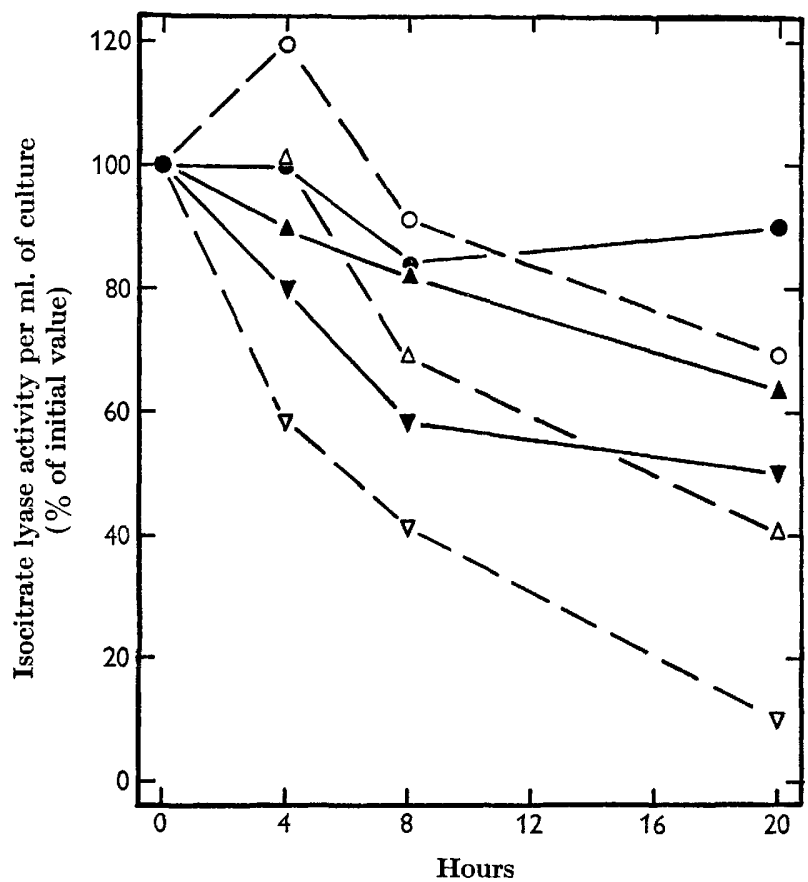

Fig. 4. The effect of nitrogen starvation of Chlorella vulgaris on isocitrate lyase activity. Organisms were shaken in darkness, at $25^{\circ}$, in $0 \cdot 07 \mathrm{M}$-phosphate ( $\mathrm{pH} \mathrm{6 \cdot 7)}$ with the following additions: $-\bullet--, 0 \cdot 2 \%$ acetate $+N ;-\nabla-\nabla-, 0.5 \%$ glucose $+\mathbf{N} ;-\boldsymbol{A}-\boldsymbol{\Delta}-$, no carbon source $+\mathbf{N}$. $\cdot-O-O-, 0 \cdot 2 \%$ acetate $-N ;-\nabla-\nabla-, 0 \cdot 5 \%$ glucose $-N ;-\triangle-\triangle-$, no carbon source $-\mathrm{N}$. Nitrogen was supplied as $0.01 \mathrm{M}$-ammonium nitrate. Change in enzyme activity was stopped, at the times shown, by freezing the suspension. The number of organisms did not change markedly during the experiment except when glucose was present; in the absence of nitrogen, the number of organisms then increased two- to threefold; in its presence it increased fourfold. Isocitrate lyase activity per organism therefore declined more steeply in the glucose cultures than the graph shows.

between 1 and $2 \mu \mathrm{g}$. nitrate-N/mg. dry weight organism/hr. In contrast, cell-free extract from equiv. $1 \mathrm{mg}$. dry wt. nitrogen-starved organisms contained only enough activity to reduce $0.5 \mu \mathrm{g}$. nitrate-N/hr. The observed rate of nitrate assimilation by intact nitrogen-starved organisms was $4-4.5 \mu \mathrm{g}$. nitrate-N/mg. dry wt./hr. Thus, whereas extracts of nitrate-grown organisms possessed an excess of nitrate reductase in comparison with the rate at which whole organisms reduced nitrate, extracts from 
nitrogen-starved organisms contained only about $10-12 \%$ of the activity equivalent to the observed rate of nitrate reduction by these organisms.

\section{The effect of nitrogen starvation on isocitrate lyase activity}

Isocitrate lyase activity is high in Chlorella grown on acetate in darkness (Syrett et al. 1963). When such organisms were transferred to nitrogen-free medium for $20 \mathrm{hr}$, isocitrate lyase activity declined to about $70 \%$ of the original value (Fig. 4). Greater decreases were observed when acetate was removed and particularly when it was replaced by glucose. The results in Fig. 4 are expressed as enzyme activity/ unit volume culture. In those cultures supplied with glucose, the numbers of organisms increased during the experiment; activities expressed/organism would therefore show more marked changes in such cultures than is apparent from Fig. 4.

\section{Table 1. The effect of nitrogen starvation on the activity of the malic dehydrogenase of Chlorella vulgaris}

No significant change in number of organisms was observed during nitrogen starvation. The organisms were starved of nitrogen for $16 \mathrm{hr}$ under autotrophic conditions. $(a)$ and (b) denote duplicate extractions from the same culture.

$\begin{array}{lccc}\begin{array}{c}\text { Nitrogen } \\ \text { source for } \\ \text { growth }\end{array} & \text { Expt. } & \overbrace{\text { Normal organisms }}^{\begin{array}{c}\text { Malic dehydrogenase activity } \\ (\mathrm{m} \mu \text { moles NADH oxidized/mg. protein/min. })\end{array}} \\ \mathrm{KNO}_{3} & 1 & (\text { a }) \mathbf{1 5 6 0} & \text { N-starved organisms } \\ & 2 & (\text { b) } 2610 & 1650 \\ \left(\mathrm{NH}_{4}\right)_{2} \mathrm{SO}_{4} & 1 & - & 1340 \\ & 2 & 1720 & 2060 \\ & 1 & 2000 & 1940\end{array}$

Table 2. The effect of nitrogen starvation on the activities of glutamic dehydrogenase and nitrate reductase in Chlorella vulgaris

Nitrogen-starved cultures of Chlorella vulgaris were prepared by aeration under autotrophic conditions for $16 \mathrm{hr}$. A maximum of $40 \%$ increase in number of organisms during nitrogen starvation was observed in some cultures. The experiment numbers denote replicate cultures; $(a)$ and $(b)$ denote duplicate extractions of the same culture.

\begin{tabular}{|c|c|c|c|c|c|}
\hline \multirow[b]{2}{*}{$\begin{array}{l}\text { Nitrogen } \\
\text { source for } \\
\text { growth }\end{array}$} & \multirow[b]{2}{*}{ Expt. } & \multicolumn{2}{|c|}{$\begin{array}{l}\text { Nitrate reductase activity } \\
\left(\mathrm{m} \mu \text { moles } \mathrm{NO}_{2}^{\prime} / \mathrm{mg} .\right. \\
\text { protein } / \mathrm{min} .)\end{array}$} & \multicolumn{2}{|c|}{$\begin{array}{l}\text { Glutamic dehydrogenase } \\
\text { activity (m } \mu \text { moles NADPH } \\
\text { oxidized/mg. protein/min.) }\end{array}$} \\
\hline & & $\begin{array}{c}\text { Normal } \\
\text { organisms }\end{array}$ & $\begin{array}{l}\mathrm{N} \text {-starved } \\
\text { organisms }\end{array}$ & $\begin{array}{c}\text { Normal } \\
\text { organisms }\end{array}$ & $\begin{array}{l}\mathrm{N} \text {-starved } \\
\text { organisms }\end{array}$ \\
\hline $\mathrm{KNO}_{3}$ & 1 & $\begin{array}{l}\text { (a) } 26 \cdot 2 \\
\text { (b) } 34 \cdot 0\end{array}$ & $5 \cdot 1$ & $\begin{array}{l}\text { (a) } 48.0 \\
\text { (b) } 48.3\end{array}$ & $99 \cdot 0$ \\
\hline & $\begin{array}{l}2 \\
3\end{array}$ & - & $\begin{array}{l}4 \cdot 3 \\
6 \cdot 2\end{array}$ & - & $\begin{array}{l}78 \cdot 5 \\
66 \cdot 5\end{array}$ \\
\hline$\left(\mathrm{NH}_{4}\right)_{2} \mathrm{SO}_{4}$ & $\begin{array}{l}1 a \\
1 b\end{array}$ & $-^{0.9}$ & $\begin{array}{l}4 \cdot 0 \\
6 \cdot 0\end{array}$ & $\begin{array}{l}74 \cdot 0 \\
-\end{array}$ & $\begin{array}{r}116 \cdot 0 \\
95 \cdot 0\end{array}$ \\
\hline
\end{tabular}




\section{The effect of nitrogen starvation on malic dehydrogenase and glutamic dehydrogenase activity}

Nitrogen starvation appeared to have no effect on malic dehydrogenase activity (Table 1). The activity of glutamic dehydrogenase extracted from nitrogen-starved organisms was greater than from normal organisms, the increase in activity varying between 40 and $100 \%$ (Table 2). The increase was similar when either ammoniumgrown or nitrate-grown organisms were starved of nitrogen, but generally the activity extracted from anmonium-grown organisms was about $40 \%$ greater than from nitrate-grown organisms.

By a calculation similar to that above for nitrate reductase activity, it can be shown that the glutamic dehydrogenase activity of nitrogen-starved Chlorella was about equal to the rate at which whole organisms assimilated ammonium, while the activity in extracts of normal organisms was about three times that required to account for the rate of ammonium assimilation by whole normal organisms. However, this comparison assumes that all the ammonium assimilation by intact cells proceeds through glutamic dehydrogenase. The recent work of Sims \& Folkes (1964) with yeast indicates that this may not be so; other pathways of ammonium assimilation must exist, to the guaninido group of arginine, for example. Consequently, from both normal and nitrogen-starved organisms, the extracted glutamic dehydrogenase activity probably exceeded the activity of this enzyme in vivo.

\section{DISCUSSION}

The effect of nitrogen starvation of Chlorella vulgaris on the activity of the two constitutive enzymes, malic dehydrogenase and glutamic dehydrogenase, differed from its effect on the inducible enzymes isocitrate lyase and nitrate reductase. The activity of malic dehydrogenase was unchanged after nitrogen starvation while that of glutamic dehydrogenase increased. Barratt (1963) showed that the glutamic dehydrogenase activity of Neurospora increased after nitrogen starvation and concluded that excess available nitrogen repressed the formation of this enzyme; our results are consistent with this interpretation.

In contrast, isocitrate lyase activity decreased when Chlorella was starved of nitrogen. The decrease was much greater when the inducer acetate was replaced by glucose, which represses isocitrate lyase formation in this organism (Syrett et al. 1963). Glucose serves as a readily available carbon source for Chlorella and, in its presence, the organisms multiplied during the experimental period even in the absence of nitrogen; thus the drain on available nitrogen in the organisms was larger when glucose was supplied. The behaviour of the other inducible enzyme, nitrate reductase, resembled that of isocitrate lyase in that the high nitrate reductase activity in nitrate-grown organisms declined rapidly when the organisms were nitrogen-starved. Transfer to an ammonium medium had a similar effect; ammonium is known to repress the formation of nitrate reductase (Morris \& Syrett, 1963).

Two explanations of these effects are possible: (i) the rate of turnover of nitrate reductase and isocitrate lyase is always rather fast and, when synthesis is prevented by the removal of an inducer or the addition of a repressor, this results in a rapid loss of activity; or (ii) the conditions used, i.e. nitrogen starvation in the presence of freely available carbon, in some way stimulate the breakdown of these enzymes. The 
behaviour of isocitrate lyase, in particular, resembles that of the inducible enzyme galactozymase in a yeast. Spiegelman \& Reiner (1947) showed that this enzyme was lost when the substrate was removed and the loss was much faster when the yeast was incubated with glucose in the absence of a nitrogen source. They suggested that the enzyme was not inherently unstable in the absence of its substrate and that its rapid loss on incubation with glucose was a consequence of the synthesis of other enzymes. This explanation appears to imply a balance between the induced enzyme molecules and amino acids which is shifted towards breakdown when the amino acids are used for the synthesis of other proteins. It is uncertain whether this is so, but the hypothesis would explain why loss of enzyme was faster when an exogenous nitrogen source was not available.

Ammonium-grown Chlorella acquired nitrate reductase activity and the capacity to assimilate nitrate after a short period of nitrogen starvation. Evidently the presence of nitrate was not essential for the formation of this enzyme. Nitrogenstarved Chlorella, whether grown on nitrate or ammonium initially, assimilated nitrate rapidly and at a rate some ten times higher than the nitrate reductase activity recovered in cell-free extracts should allow. It appears that only a proportion of the nitrate reductase activity of whole nitrogen-starved cells was recovered in cell-free extracts. If the same is true for normal nitrate-grown organisms, which assimilate nitrate more slowly but show considerably higher nitrate reductase activities in extracts, this would imply that much of the nitrate reductase activity of normal nitrate-grown Chlorella is inhibited in vivo. There is evidence for an inhibition of nitrate reductase by a product of ammonium assimilation (Syrett \& Morris, 1963); possibly, too, an inhibitor is formed during nitrate assimilation by normal nitrate-grown Chlorella.

\section{REFERENCES}

Barratt, R. W. (1963). Effect of environmental conditions on the NADP-specific glutamic acid dehydrogenase in Neurospora crassa. J. gen. Microbiol. 33, 33.

Bongers, L. H. J. (1956). Aspects of nitrogen assimilation by cultures of green algae. Meded. LandbHoogesch., Wageningen, 56, 1.

Lowry, O. H., Rosebrough, N. J., Farr, A. L. \& Randall, R. J. (1951). Protein measurement with the Folin phenol reagent. J. biol. Chem. 193, 265.

Monris, I. \& Syrett, P. J. (1963). The development of nitrate reductase in Chlorella and its repression by ammonium. Arch. Mikrobiol. 47, 32.

Morton, A. G., Dickerson, F. \& England, D. J. F. (1960). Changes in enzyme activity of fungi during nitrogen starvation. J. exp. Bot. 11, 116.

Sims, A. P. \& Folkes, B. F. (1964). A kinetic study of the assimilation of [ ${ }^{15 N]}$-ammonia and the synthesis of amino-acids in an exponentially growing culture of Candida utilis. Proc. roy. Soc. B, 159, 479.

Spiegelman, S. \& Reiner, J. M. (1947). The formation and stabilization of an adaptive enzyme in the absence of its substrate. J. gen. Physiol. 31, 175.

Syrett, P. J. (1953). The assimilation of ammonia by nitrogen-starved cells of Chlorella vulgaris. I. Ann. Bot., Lond. 17, 1.

SyrETt, P. J. (1956). The assimilation of ammonia and nitrate by nitrogen-starved cells of Chlorella vulgaris. II. The assimilation of large quantities of nitrogen. Physiol. Plant. $9,19$.

Syrett, P. J., Merrett, M. J. \& Bocks, S. M. (1963). Enzymes of the glyoxylate cycle in Chlorella vulgaris. J. exp. Bot. 14, 249.

Syrett, P. J. \& Morris, I. (1963). The inhibition of nitrate assimilation by ammonium in Chlorella. Biochim. biophys. Acta, 67, 566. 